\title{
Effect of Red Dragon Fruit Juice on Acrylic Resin Color
}

\author{
Fransiska Nuning Kusmawati ${ }^{a^{*}}$, Diah Puspitasari Kusumaningrum ${ }^{\mathrm{b}}$ \\ ${ }^{a}$ Department of Prosthodonsia, Faculty of Dentistry, Universitas Prof DR. Moestopo (Beragama), Jakarta, Indonesia. \\ ${ }^{b}$ Clinical Student Department of Prosthodonsia, Faculty of Dentistry, Universitas Prof. DR. Moestopo (Beragama), Jakarta, Indonesia.
}

Received 30 May 2019; Accepted 21 August 2019

\begin{abstract}
Background: Discoloration of denture acrylic resin base is one of the problems in appearance for patients who use them. The most common habit can cause discoloration in the denture usually associated with the patient's diet. One example is consuming red dragon fruit juice. Red dragon fruit juice contains many anthocyanin substances that can give color from colorless to purple. Furthermore, color changes indenture can also cause by the characteristic of the acrylic resin plate itself which can absorb water due to porosity. Objective: The aim of this study is to investigate the negative effects of consuming red dragon fruit juice solution on heat cured acrylic resin based plate. Methods: This type of research is laboratory experimental and the design of this research is pre-test post-test with control group design. The number of samples were 32 pieces selected using Simple Random Sampling method. The samples were divided into two groups, control ( $\mathrm{n}=16$, distilled water solution) and tentative $(n=16$, red dragon fruit juice solution). Color measurement using a digital spectrophotometer (VITA Easyshade). The initial color of the plate was measured before immersion into dragon fruit juice. The immersion period were 7 days to 14 days, the color of the plates was then measured after immersion. The data analysis test used was Friedman statistical test and Mann Whitney statistical test. Findings: There were significant differences in the color of the heat-cured acrylic resin plate after 7 and 14 days of immersion in distilled water solution and red dragon fruit juice solution. Novelty: Red dragon fruit juice can cause color discoloration on heat cured acrylic resin based plate.
\end{abstract}

Keywords: Red Dragon Fruit Juice Solution; Acrylic Resin Plate Discoloration; Heat- cured Acrylic Resin Base.

\section{Introduction}

Nowadays, the level of public awareness of dental health is increasing. This allows increased of dentures uses with bases made of acrylic resin [1]. According to the type of polymerization, there are two types of acrylic resins which are heat-cured type and the cold-cured type. Discoloration of acrylic resin can be caused by several factors, one of them is the ability of acrylic resin to absorb liquid. Discoloration of acrylic resin is not only related to physical and chemical properties, but also related to the patient's diet [2].

Hylocereus polyrhizus or red dragon fruit is often called red pitaya because both skin and flesh colors are red. The complete nutritional and vitamin content and phytochemicals in the form of flavonoids in dragon fruit are also known to reduce the risk of cancer. However, the presence of some of these substances might affect the discoloration of the acrylic denture base [3].

\subsection{Heat-cured Acrylic Resin}

Acrylic resin as a denture base is still being used due to its several advantages including good aesthetic, non-toxic, easy to be manipulated, affordable and easy to be repaired. Among other acrylic resin materials, Polymethyl methacrylate (PMMA) is the most popular acrylic resin material that is used for denture base material $[4,5]$.

* Corresponding author: nuningphynx@gmail.com

$>$ This is an open access article under the CC-BY license (https://creativecommons.org/licenses/by/4.0/).

(C) Authors retain all copyrights. 
Heat-cured acrylic resins commonly used in dentistry as artificial teeth base. Heat-cured acrylic resin is hot polymerization acrylic resin with heat-activated ingredients. Thermal energy needed for the polymerization of these materials can be obtained by using water heating [6].

One of the drawbacks of using acrylic resin as a denture base is that fractures often occur due to usage, poor thermal conductor, porosity, absorbing liquid, and abrasion during cleaning. Liquid absorption of heat-cured acrylic resin is also one of the disadvantages of using acrylic resin as a denture base.

There are four types of dragon fruit that have been cultivated in Indonesia, namely white flesh dragon fruit (Hylocereus undatus), red meat dragon fruit (Hylocereus polyrhizus), super red meat dragon fruit (Hylocereus costaricensis), and white flesh yellow dragon fruit (Selenicereus megalanthus). A hundred grams of red dragon fruit (Hylocereus polyrhizus) flesh contains water (82.5-83.0 g); protein (0.16-0.23 g); fat (0.21-0.61 g); niacin (1.29-1.30 $\mathrm{mg})$; vitamin C (8.0-9.0 mg); sweetness level of 13-15 briks; and anthocyanin as much as $8.8 \mathrm{mg}$ [7-10].

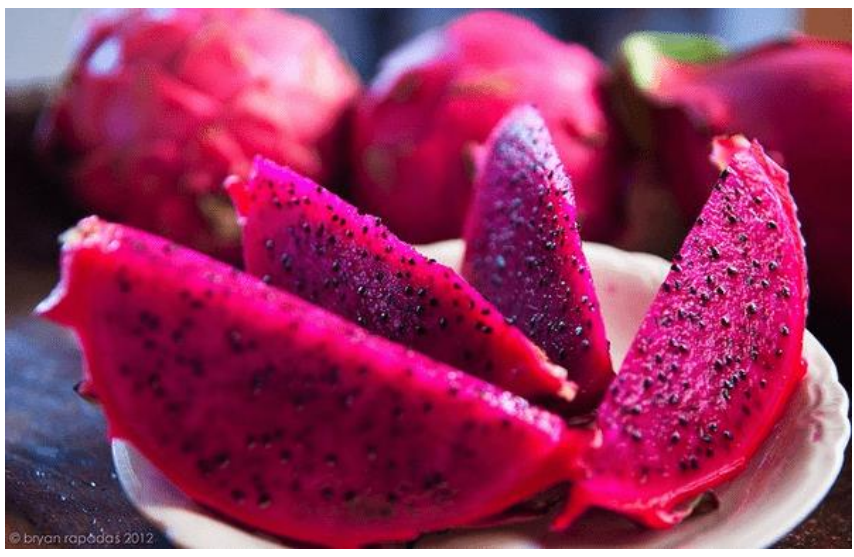

Figure 1. Red Dragon Fruit

According to research conducted by Widianingsih, the red dragon fruit also has high antioxidant activity which is 67.45 ppm [11].

Anthocyanin is a plant pigment that could be found in nature. This pigment has relevant role in plant propagation, ecophysiology, and plant defense mechanisms and gives color to fruits (red dragon fruit, blueberries, grapes, etc) and vegetables (spinach, purple cabbage and roselia flowers). Anthropyanins are phenolic compounds containing components that are soluble in water, found in various types of plants and gives color from colorless to purple. Anthocyanin is a class of flavonoid compounds which is widely divided into plant polyphenols and has a group of red to blue pigments that are scattered in plants. The pigments that found in plants have variety of benefits. ${ }^{12}$ Blue, red, and purple pigments extracted from flowers, fruits and vegetables are traditionally used as natural food coloring. Besides being used as natural coloring agent, some flowers such as roselia flower and red dragon fruit are rich in anthocyanin and have been traditionally used as medicines to treat various diseases [12].

\subsection{Color Change Measuring Instrument}

The measurement of color changes on heat-cured acrylic resin plate in this study was using digital spectrophotometer (VITA Easyshade). (Figure 2). This instrument is the latest spectrophotometer used in clinical use [13].

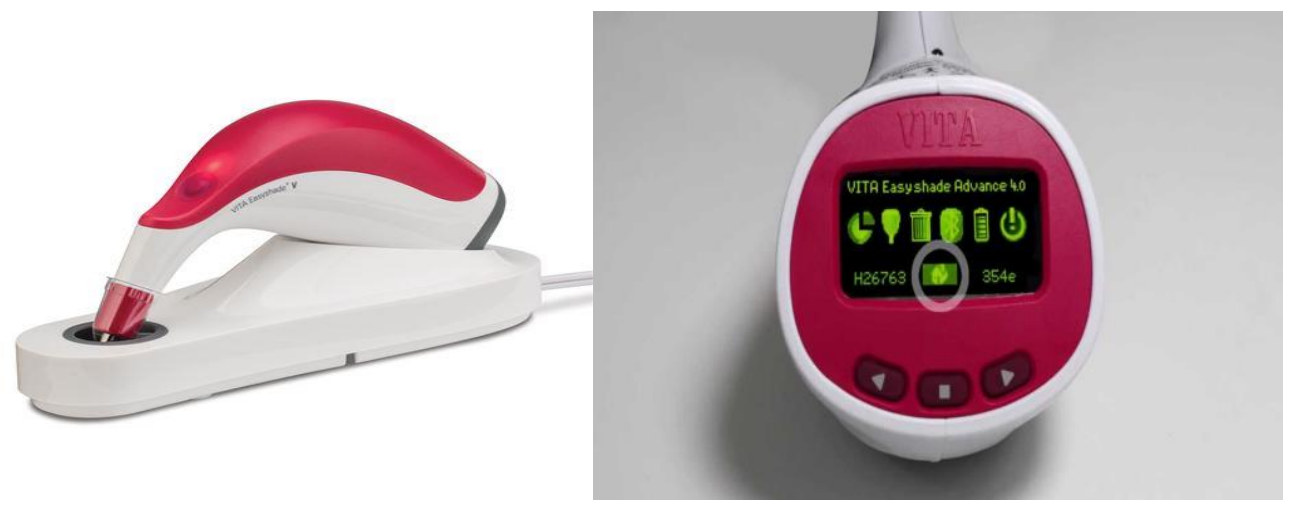

Figure 2. VITA easyshade [14] 
Color measurements are based on the use of 3 or 4 color discs, each of which has been accurately calibrated in 3 ways, namely chromatic / hue / hue color (red, green, etc.), value / brightness (lightness, darkness) and chrome (strength / color intensity). Chrome is the color intensity that distinguishes strong colors and weak colors, described as the distance of a circle from the center (Munsell color ball). Value is the color quality associated with lighting, which is the level of brightness and described as a vertical line. The color measurement of this system is to visually match the color of the product with the color of Munsell using the sense of sight [13].

\section{Research Methodology}

The design used was experimental laboratory research with a pretest-post test with control group design approach. The study was conducted in Faculty of Dentistry, Universitas Prof. DR. Moestopo (Beragama) on July 2018. Thirty two samples of heat-cured acrylic resin plates were prepared with $20 \mathrm{~mm}$ length,10 $\mathrm{mm}$ width and $1 \mathrm{~mm}$ thickness. Samples were selecty by simple random sampling.

The research procedures are carried out as follows: 1) Preparing the tools and materials to be used in the study 2) Thirty two samples were divided into group 1 and 2 with n number was 16. 3) Performed measurements with digital spectrophotometer (VITA Easyshade) on samples from each group (pretest). 4) Preparation of pure red dragon fruit juice solution by blending $168 \mathrm{gr}$ of red dragon fruit with $100 \mathrm{ml}$ of distilled water using juice blender. Juice was then poured into the container that has been prepared. 5) Group 1 was immersed into aquades. 6) Group 2 was immersed into red dragon fruit juice. 7) After 7 days, samples were rinsed with water, dried and color checked with digital spectrophotometer. 8) Samples were then immersed again into aquades and red dragon fruit juice for another 7 days. 9) After total of 14 days, samples were removed again using tweezers, rinsed with water, dried and color checked with digital spectrophotometer. 10) Record and compared the measurement results.

\section{Result}

The statistical test used in this study is the Non Parametric test which resulted in ordinal scale data. The results of the study were conducted with a descriptive test to study which group had the greatest potential in causing acrylic resin plate discoloration (Figure 3)

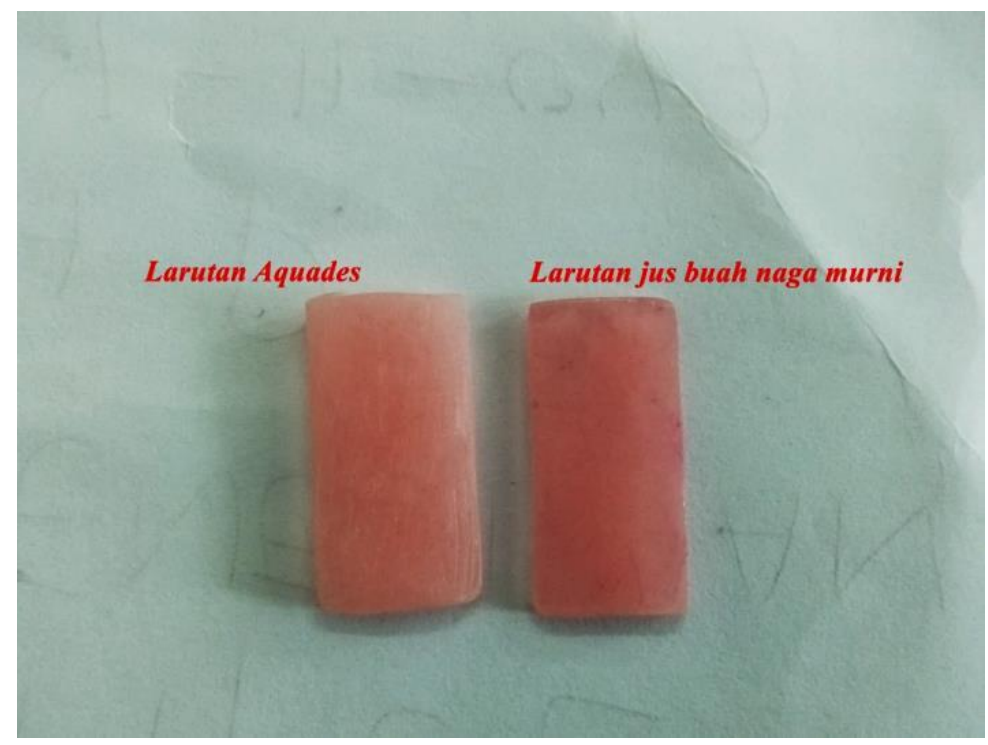

Figure 3. After 14 days immersion

Figure 4 shows the results of chrome in samples before and after immersion for 7 and 14 days. These results showed red dragon juice has the greatest potential for discoloration on heat-cured acrylic resin plate. Figure 5 shows the results of value in samples before and after immersion for 7 and 14 days. These results showed red dragon juice has the greatest potential for color change in the heat-cured acrylic resin plate. 


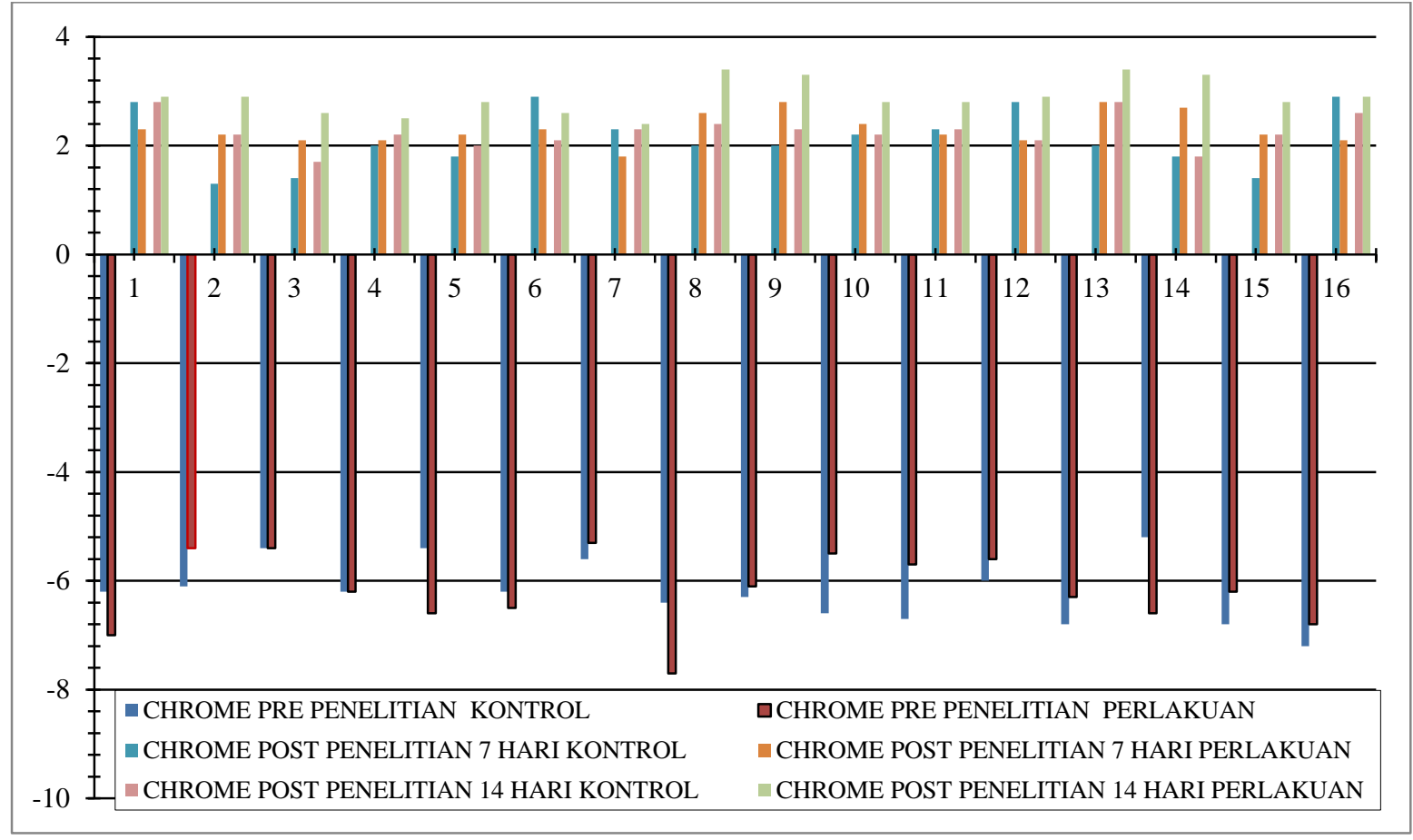

Figure 4. Chrome after immersion

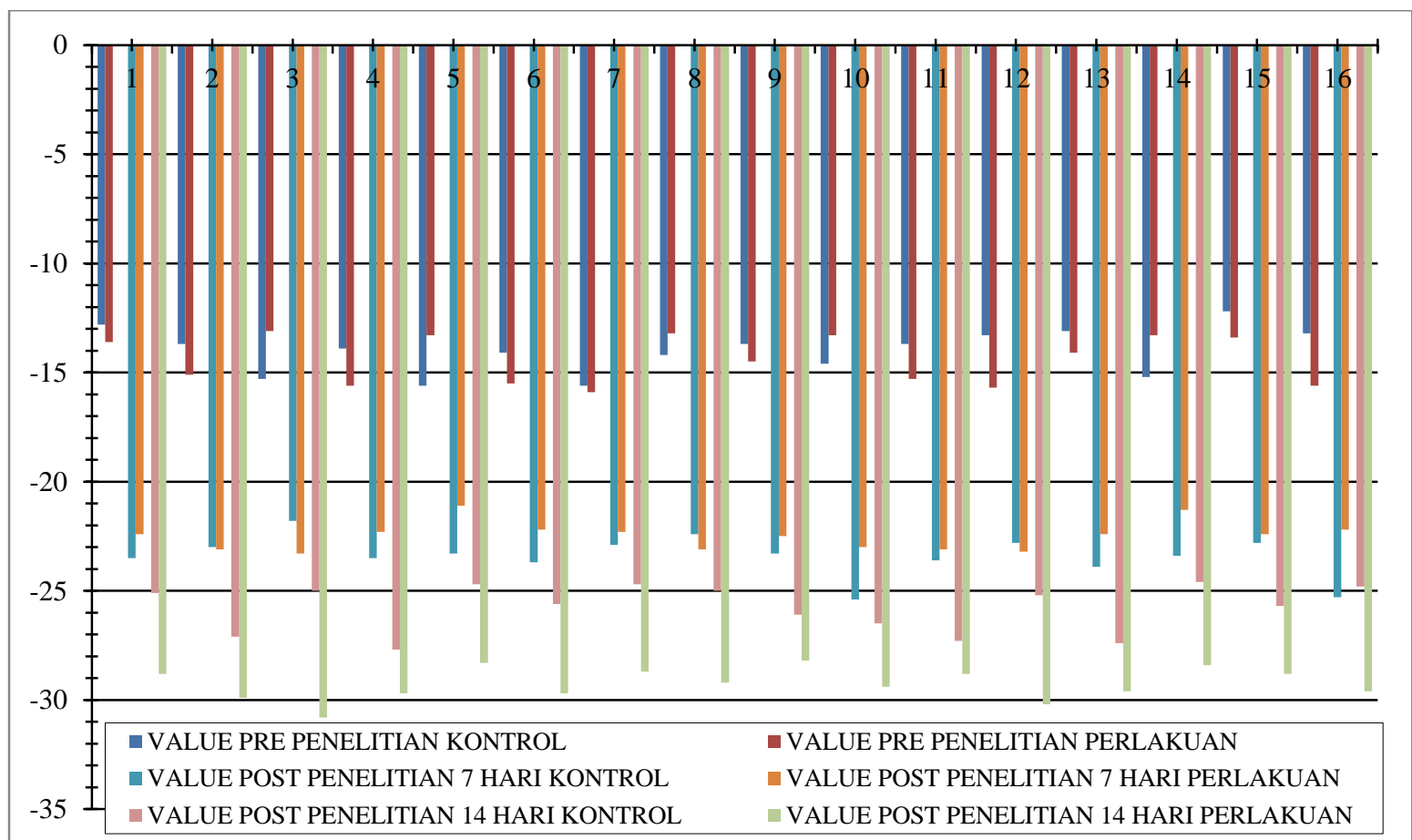

Figure 5. Value after immersion

Table 1. Friedman test Chrome

\begin{tabular}{lc}
\hline Value & Mean Ranks \\
\hline Aquades before immersion & 1.00 \\
Aquades after immersion 7days & 2.34 \\
Aquades after immerson 14 days & 2.66 \\
Red dragon juice before immersion & 1.00 \\
Red dragon juice after immersion 7 days & 2.00 \\
Red dragon juice after immersion 14 daysi & 3.00 \\
\hline \multicolumn{2}{c}{ Aquades } \\
\hline
\end{tabular}




\begin{tabular}{ll}
\hline $\mathrm{N}$ & 16 \\
Chi-Square & 26.881 \\
$\mathrm{df}$ & 2 \\
Asymp. Sig. & .000 \\
\hline \multicolumn{1}{c}{ Larutan jus buah naga merah } & \\
\hline $\mathrm{N} \quad$ & 16 \\
Chi-Square & 32.000 \\
df & 2 \\
Asymp. Sig. & .000 \\
\hline & \\
\hline Value & Mean Ranks \\
\hline Aquades before immersion & 3.00 \\
Aquades after immersion 7 days & 1.94 \\
Aquades after immersion 14 days & 1.06 \\
Red dragon juice before immersion & 3.00 \\
Red dragon juice after immersion 7 days & 2.00 \\
Red dragon juice after immersion 14 daysi & 1.00 \\
\hline Aquades & \\
\hline N & 16 \\
Chi-Square & 30.125 \\
df & 2 \\
\hline Asymp. Sig. & .000 \\
\hline Ned dragon juice & \\
Chi-Square & .000 \\
\hline Af & \\
\hline & \\
\hline
\end{tabular}

Friedman's statistical test results for both groups of heat-cured acrylic resin plates in chrome and value colors. Statistical test results on chrome color for distilled water before immersion, 7 days immersion and 14 days immersion showed a value of $\mathrm{p}=0,000(\mathrm{p}<0.05)$, meaning that there were significant differences in the color of chrome on heatcured acrylic resin tools in the control group. Statistical test results on the chrome color for red dragon fruit juice solution before immersion, 7 days immersion and 14 days immersion showed a value of $\mathrm{p}=0,000(\mathrm{p}<0.05)$, meaning that there were significant differences in the color of chrome in heat-cured acrylic resin tools in the treatment group. Statistical test results on the color value for distilled water before immersion, 7 days immersion and 14 days immersion showed a value of $\mathrm{p}=0,000(\mathrm{p}<0.05)$, meaning that there were significant differences in color values on heat-cured acrylic resin tools in the control group. Statistical test results on the color value for red dragon fruit juice solution before immersion, 7 days immersion and 14 days immersion showed a value of $p=0,000(p<0.05)$, meaning that there were significant differences in color values in the heat-cured acrylic resin tools in the treatment group.

Table 2. Mann Whitney test

Chrome

\begin{tabular}{lc}
\hline \multicolumn{2}{c}{ Before immersion } \\
\hline \multicolumn{2}{c}{ Aquades and Red dragon juice } \\
\hline Mann-Whitney U & 124.500 \\
Wilcoxon W & 260.500 \\
$\mathrm{Z}$ & -.132 \\
Asymp. Sig. (2-tailed) & .895 \\
\hline \multicolumn{2}{c}{ After immersion 7 days } \\
\hline \multicolumn{2}{c}{ Aquades and Red dragon juice } \\
\hline \multicolumn{2}{c}{ Mann-Whitney U }
\end{tabular}




\begin{tabular}{|c|c|}
\hline Wilcoxon W & 151.500 \\
\hline $\mathrm{Z}$ & -4.266 \\
\hline Asymp. Sig. (2-tailed) & .000 \\
\hline \multicolumn{2}{|c|}{ After immersion 14 days } \\
\hline \multicolumn{2}{|c|}{ Aquades and Red dragon juice } \\
\hline Mann-Whitney U & 15.500 \\
\hline Wilcoxon W & 151.500 \\
\hline $\mathrm{Z}$ & -4.266 \\
\hline Asymp. Sig. (2-tailed) & .000 \\
\hline \multicolumn{2}{|c|}{ Value test } \\
\hline \multicolumn{2}{|c|}{ Before immersion } \\
\hline \multicolumn{2}{|c|}{ Aquades and Red dragon juice } \\
\hline Mann-Whitney U & 104.500 \\
\hline Wilcoxon W & 240.500 \\
\hline $\mathrm{Z}$ & -.888 \\
\hline Asymp. Sig. (2-tailed) & .375 \\
\hline \multicolumn{2}{|c|}{ After immersion 7 days } \\
\hline \multicolumn{2}{|c|}{ Aquades and Red dragon juice } \\
\hline Mann-Whitney U & 47.000 \\
\hline Wilcoxon W & 183.000 \\
\hline $\mathrm{Z}$ & -3.059 \\
\hline Asymp. Sig. (2-tailed) & .002 \\
\hline \multicolumn{2}{|c|}{ After immersion 14 days } \\
\hline \multicolumn{2}{|c|}{ Aquades and Red dragon juice } \\
\hline Mann-Whitney U & 0.000 \\
\hline Wilcoxon W & 136.000 \\
\hline $\mathrm{Z}$ & -4.828 \\
\hline Asymp. Sig. (2-tailed) & .000 \\
\hline
\end{tabular}

The Mann Whitney statistical test results for both groups of heat-cured acrylic resin plates on chrome color and color value. Statistical test results on chrome color for aquades and red dragon fruit juice solution before immersion showed a value of $p=0.895$ ( $p>0.05$ ), this means that there is no significant difference in the color of the chrome in the heat-cured acrylic resin before the immersion of the control and treatment groups. For chrome color in aquades and 7 days immersion red dragon fruit juice solution showed a value of $p=0.197(p>0.05)$, meaning that there were no significant differences in the color of chrome in heat-cured acrylic resin tools in the 7 day immersion of the control and treatment groups. For the chrome color of distilled water and 14 days immersion red dragon fruit juice solution showed a value of $p=0,000$ ( $p<0.05)$, meaning that there were significant differences in the color of chrome in heatcured acrylic resin in the 14 day immersion of the control group and the treatment group. So it can be concluded that there are significant differences in chrome color on the heat-cured acrylic resin plate between groups in the post-test data (after 14 days immersion).

\section{Discussion}

In this study, each of the heat-cured acrylic resin plates were immersed according to their groups for 7 days and continued for up to 14 days. Determination of immersion time for 7 days refers to research conducted by Turkun, because it is assumed to be identical with the use of artificial teeth from heat-cured acrylic resin by drinkers of red dragon fruit juice for 2 years. Red dragon fruit juice drinker is a person who has a habit of consuming red dragon fruit juice drink once a day. The estimation time of a person to drink dragon fruit juice is about 15 minutes. Immersion for 7 days is equivalent to 2 years of use, and immersion for 14 days is equivalent to 4 years of use that calculated in equations below. 
$\frac{14 \text { days } \times 24 \text { hours } \times 60 \text { minutes }}{15 \text { minutes }}=1344$ days $(4$ years $)$

This study uses a heat-cured acrylic resin plate due to the increasing level of public awareness of dental health. This allows increased use of dentures with the basic ingredients made of acrylic resin [1]. Acrylic resin materials have advantages such as non-toxic, does not irritate tissue, meet aesthetic requirements, relatively cheap prices, easy to be manipulated and repaired. In addition to its beneficial properties, acrylic resins have several disadvantages including porosity which results in absorbing water or liquid, food scraps or chemicals and less abrasion resistance. ${ }^{15}$ Acrylic resin materials have the property of absorbing water gradually over a period of time with absorption mechanism through the diffusion of water molecules according to the law of diffusion [15].

The results of this study indicated that solution of pure red dragon fruit juice caused discolouration on heat-cured acrylic resin plates. This occurs due to the imbibition process experienced by acrylic resin plates against anthocyanin substances that present in red dragon fruit. This process occurs because polymethyl metalkrylate which is the basic material of acrylic resin has a tendency to absorb water through the imbibition process. Since non-crystalline structure has high internal energy, molecular diffusion could occur in the resin.

Color changes of heat-cured acrylic resin plate due to immersion in pure red dragon fruit juice solution can be caused by several factors. The first factor is the characteristic of the acrylic resin itself which can absorb liquid. The second factor is the intensity of consuming red dragon fruit. The third factor is the porosity of acrylic resin which can absorb water or liquid, food scraps or chemicals and is less abrasion resistant. The fourth factor is the surface roughness of acrylic resin, if the surface roughness is large it can be a place of accumulation of dye stains that cause color changes.

\section{Conclusion and Recommendation}

Based on the results of research on the changes in the color of the heat-cured acrylic resin plate after immersion in red dragon fruit juice solution, it can be concluded that color changes that occur on the heat-cured acrylic resin plate can be caused by solution of red dragon fruit juice (Hylocereus polyrhizus). What can be done to progress this research going forward is:

- Conduct research with a larger sample and experiment with a longer soaking time to get a more accurate final result.

- Add a dose to the solution of the red dragon fruit juice with different consistency in order to get more accurate results.

\section{Declaration of Competing Interest}

The authors declare that they have no known competing financial interests or personal relationships that could have appeared to influence the work reported in this paper.

\section{Ethical Approval}

All procedures performed in studies involving human participants were in accordance with the ethical standards of the institutional and/or national research committee and with the 1964 Helsinki declaration and its later amendments or comparable ethical standards.

\section{References}

[1] Depertemen Kesehatan Republik Indonesia. Laporan Riset Kesehatan Dasar Nasional 2013. Jakarta: Badan Penelitian dan Pengembangan Kesehatan, 149.

[2] Anusavice KJ. (2012). Science of Dental Materials, 12th Ed. Philadelphia: W.B. Saunders Co.; 237-51.

[3] Herdini L. (2015). Uji Efektivitas Ekstrak Daging Buah Naga Merah (Hylocereus polyrhizus) Terhadap Pertumbuhan Candida albicans Pada Plat Dasar Gigi Tiruan Resin Akrilik [skripsi]. Yogyakarta: Universitas Gajah Mada. Available online: http://etd.repository.ugm.ac.id/index.php?mod=penelitian_detail\&sub=PenelitianDetail\&act=view\&typ=html\&buku_id=84395 \&obyek_id=4 (accessed on 12 July 2018).

[4] Siswanto A. (2007). The Influence of Soaking Acrylic Plate in Leracs Condensation to Strength Transversa. Journal of Indonesian Dent Association 57(3), 97-100.

[5] Anonim. Sifat Resin Akrilik (Biologis, Kimia, Fisika). November 2011. Available online: https://www.scribd.com/document/190182630/Sifat-Resin-Akrilik-Biologis-Kimia-Fisika (accessed on 12 April 2018). 
[6] Craig RG, Powers JM. (2006). Restorative Dental Materials. 12th Ed. St. Louis CV Mosby Company, 513-53.

[7] Sitorus Zu, Eddy Dahar (2012). Perbaikan Sifat Fisis dan Mekanis Resin Akrilik Polimerisasi Panas Dengan Penambahan Serat Kaca. Dentika Dental Journal. 17 (1), 24-9.

[8] Haryanto, A. G., Margo, A., Burhan, L. K., Suryatenggara, F., \& Setiabudi, I. (2012). Buku ajar gigi geligi tiruan sebagian lepasan jilid 1. Jakarta: Hipokrates, 4-15.

[9] Handayani, P. A., \& Rahmawati, A. (2012). Pemanfaatan kulit buah naga (dragon fruit) sebagai pewarna alami makanan pengganti pewarna sintetis. Jurnal bahan alam terbarukan, 1(2).

[10] Kres Dahana, S. P., \& Warisno, S. (2013). Buku pintar bertanam buah naga. Gramedia Pustaka Utama.

[11] Widianingsih, M. (2017). Aktivitas antioksidan ekstrak metanol buah naga merah (Hylocereus polyrhizus (FAC Weber) Britton \& Rose) hasil maserasi dan dipekatkan dengan kering angin. Jurnal Wiyata: Penelitian Sains dan Kesehatan, 3(2), 146150 .

[12] Khoo, H. E., Azlan, A., Tang, S. T., \& Lim, S. M. (2017). Anthocyanidins and anthocyanins: colored pigments as food, pharmaceutical ingredients, and the potential health benefits. Food \& Nutrition Research, 61(1), 1361779. doi:10.1080/16546628.2017.1361779.

[13] Suyatma NE. (2009). Analisis Warna. Available online: http://slideplayer.info/slide/3239849/. (accessed on 14 April 2018).

[14] Zahnfabrik (2017). Vita Easyshade. Available online: https://www.vita-zahnfabrik.com/en/VITA-Easyshade-26934,27568.html (accessed on 17 April 2018).

[15] Rianti, D., \& Munadziroh, E. (2000). Perubahan Warna Resin Akrilik untuk Basis Gigi Tiruan dan Mahkota Jaket Akibat Jus Apel. Journal of Dentistry Indonesia, 7(3), 650-654. 